THE VIETNAM WAR 
PROBLEMS IN FOCUS: MANCHESTER

General Editor: Brian Pullan

Published

Jeffrey Denton

Orders and Hierarchies in Late Medieval and Renaissance Europe

Peter Lowe

The Vietnam War 


\title{
THE VIETNAM WAR
}

\author{
Edited by \\ Peter Lowe \\ Reader in History \\ University of Manchester
}


Selection, editorial matter and Introduction (C) Peter Lowe 1998

Chapter 1 (C) Anthony Short 1998; Chapter 2 (C) Nguyen Vu Tung 1998;

Chapter 3 (C) Ngo Vinh Long 1998; Chapter 4 (C) David L. Anderson 1998;

Chapter 5 (C) Tom Wells 1998; Chapter 6 (C) Ilya V. Gaiduk 1998;

Chapter 7 (C) Chen Jian 1998; Chapter 8 (C) Carl Bridge 1998;

Chapter 9 (C) Alastair Parker 1998

All rights reserved. No reproduction, copy or transmission of this publication may be made without written permission.

No paragraph of this publication may be reproduced, copied or transmitted save with written permission or in accordance with the provisions of the Copyright, Designs and Patents Act 1988, or under the terms of any licence permitting limited copying issued by the Copyright Licensing Agency, 90 Tottenham Court Road, London W1P 9HE.

Any person who does any unauthorised act in relation to this publication may be liable to criminal prosecution and civil claims for damages.

The authors have asserted their rights to be identified as the authors of this work in accordance with the Copyright, Designs and Patents Act 1988.

First published 1998 by MACMILLAN PRESS LTD

Houndmills, Basingstoke, Hampshire RG21 6XS and London

Companies and representatives throughout the world

ISBN 978-0-333-65831-4 ISBN 978-1-349-26949-5 (eBook) DOI 10.1007/978-1-349-26949-5

A catalogue record for this book is available from the British Library.

This book is printed on paper suitable for recycling and made from fully managed and sustained forest sources.

$\begin{array}{rrrrrrrrrr}10 & 9 & 8 & 7 & 6 & 5 & 4 & 3 & 2 & 1 \\ 07 & 06 & 05 & 04 & 03 & 02 & 01 & 00 & 99 & 98\end{array}$




\section{CONTENTS}

Acknowledgements vii

Abbreviations viii

Notes on the Contributors $\quad \mathrm{x}$

Map of Vietnam xii

Introduction

Peter Lowe 1

1 Origins and Alternatives: Comments, Counter-Facts and Commitments

Anthony Short $\quad 9$

2 Coping with the United States: Hanoi's Search for an Effective Strategy

Nguyen Vu Tung $\quad 30$

3 South Vietnam

Ngo Vinh Long $\quad 62$

4 The United States and Vietnam
David L. Anderson

5 The Anti-Vietnam War Movement in the United States Tom Wells

6 Developing an Alliance: The Soviet Union and Vietnam, 1954-75

Ilya V. Gaiduk 
vi

Contents

7 China and the Vietnam Wars, 1950-75

Chen Jian

152

8 Australia and the Vietnam War

Carl Bridge

9 International Aspects of the Vietnam War Alastair Parker

Notes and References

Index 


\section{ACKNOWLEDGEMENTS}

I am most grateful to Professor Brian Pullan for inviting me to edit the first volume in a new series, associated with the Department of History in the University of Manchester, of which he is the general editor. I have been greatly encouraged by the enthusiasm and vigour revealed by the contributors to this volume. They have responded carefully and effectively to produce lucid, concise surveys of the principal issues relating to the country or theme examined in their essays. The outcome is a trenchant analysis of developments determining the course of the conflict in Vietnam. Professor Stein Tønnesson gave me helpful advice at an early stage of planning which was much appreciated. I have received additional encouragement and guidance from the staff of Macmillan, particularly from Jonathan Reeve. I am grateful to Keith Povey for his considerable assistance as copy-editor. Finally, I wish to thank Jean Davenport for her customary efficiency in assisting with typing.

The editor and publishers wish to thank the following for permission to use copyright material:

Oxford University Press for reuse of material from Chen Jian 'China and the first Indo-China War 1950-1954' (March 1993) and 'China's Involvement in the Vietnam War, 1964-1969' (July 1995), both published in The China Quarterly.

Peter Lowe 


\section{ABBREVIATIONS}

AATV Australian Army Training Team, Vietnam

ALP Australian Labor Party

ANZAM Australia, New Zealand and Malay Agreement

ANZUS Australia, New Zealand, United States Agreement

ARVN Army of the Republic of Vietnam (South Vietnam)

BRIAM British Advisory Mission

CCP Chinese Communist Party

CCDS Central Committee Directorate for the South

CIA Central Intelligence Agency

CMAG Chinese Military Advisory Group

COSVN Central Office for South Vietnam

CPSU Communist Party of the Soviet Union

DLP Democratic Labor Party

DRV Democratic Republic of Vietnam (North Vietnam)

FBI Federal Bureau of Investigation

GVN Government of South Vietnam

ICC International Control Commission

ICP Indochinese Communist Party

LBJ Lyndon Baines Johnson

MACV Military Assistance Command, Vietnam

NATO North Atlantic Treaty Organization

NLF National Liberation Front

NSC National Security Council

NVA North Vietnamese Army

PAVN People's Army of Vietnam (North Vietnam)

PLA People's Liberation Army (China)

PLAVN People's Liberation Army (North Vietnam)

PRC People's Republic of China

PRG People's Revolutionary Government

RAN Royal Australian Navy 
ROTC Reserve Officers Training Corps

RVN Republic of Vietnam (South Vietnam)

SANE Committee for a Sane Nuclear Policy

SDS Students for a Democratic Society

SEATO South East Asia Treaty Organization

SWP Socialists Workers Party

UN United Nations

US United States

VWP Vietnamese Workers Party 


\section{NOTES ON THE CONTRIBUTORS}

David L. Anderson is Professor of History and Chair of the Department of History and Political Science at the University of Indianapolis. His books include Trapped by Success: the Eisenhower Administration and Vietnam (1991), Shadow on the White House: Presidents and the Vietnam War (1993), and Facing My Lai: Moving beyond the Massacre (1998).

Carl Bridge is Professor of Australian Studies and Head of the Sir Robert Menzies Centre for Australian Studies, University of London. His recent works include two edited books, Munich to Vietnam (Melbourne, 1991) and Manning Clark (Melbourne, 1994).

Chen Jian is an Associate Professor of History at Southern Ilinois University and was a senior fellow at the United States Institute of Peace for the 1996-7 academic year. He has taught previously at East China Normal University, Tibetan Nationality College, and the State University of New York at Geneseo. Among his publications are China's Road to the Korean War (1994) and Chinese Communist Foreign Policy and the cold war in Asia (co-editor, 1996).

Ilya V. Gaiduk is a research fellow at the Institute of World History in Moscow, specializing in Soviet-American relations. He has been a fellow of the cold war International History Project at the Woodrow Wilson Center for Scholars in Washington, DC and of the Norwegian Nobel Institute. He is the author of The Soviet Union and the Vietnam War (1996).

Ngo Vinh Long is Associate Professor of Asian Studies at the University of Maine, teaching courses on China, Japan, South Asia, South-East Asia, and the United States' relations with Asian countries. He serves as a coordinator of several research projects on social and economic issues 
in Vietnam. His publications include Before the Revolution: The Vietnamese Peasants under the French $(1973,1991)$, Vietnamese Women in Society and Revolution (1974) and Coming to Terms: The United States, Indochina and the War (co-editor, 1991).

Peter Lowe is Reader in History at the University of Manchester. Among his publications are Containing the cold war in East Asia: British Policies towards Japan, China and Korea, 1948-1953 (1997) and The Origins of the Korean War, second edition (1997).

Alastair Parker studied Modern History at Christ Church, Oxford. After serving as a lecturer in the University of Manchester, he became a Fellow of Queen's College, Oxford in 1957. His recent publications include Struggle for Survival: the History of the Second World War (1989) and Chamberlain and Appeasement (1993).

Anthony Short was formerly Reader in International Relations and Warden of Dunbar Hall in the University of Aberdeen. Among his publications are The Communist Insurrection in Malaya, 1948-1960 (1975) and The Origins of the Vietnam War (1989).

Nguyen Vu Tung is a graduate of the Fletcher School of Law and Diplomacy, Tufts University. $\mathrm{He}$ is a researcher at the Institute of International Relations, Hanoi, and is the author of a number of articles on political and security developments in contemporary South-East Asia.

Tom Wells earned a PhD in Sociology from the University of California, Berkeley, and has taught at the University of San Francisco, San Jose State University and Mills College. He is the author of The War Within: America's Battle over Vietnam (1994, paperback, 1996). He is currently writing a biography of Daniel Ellsberg. 


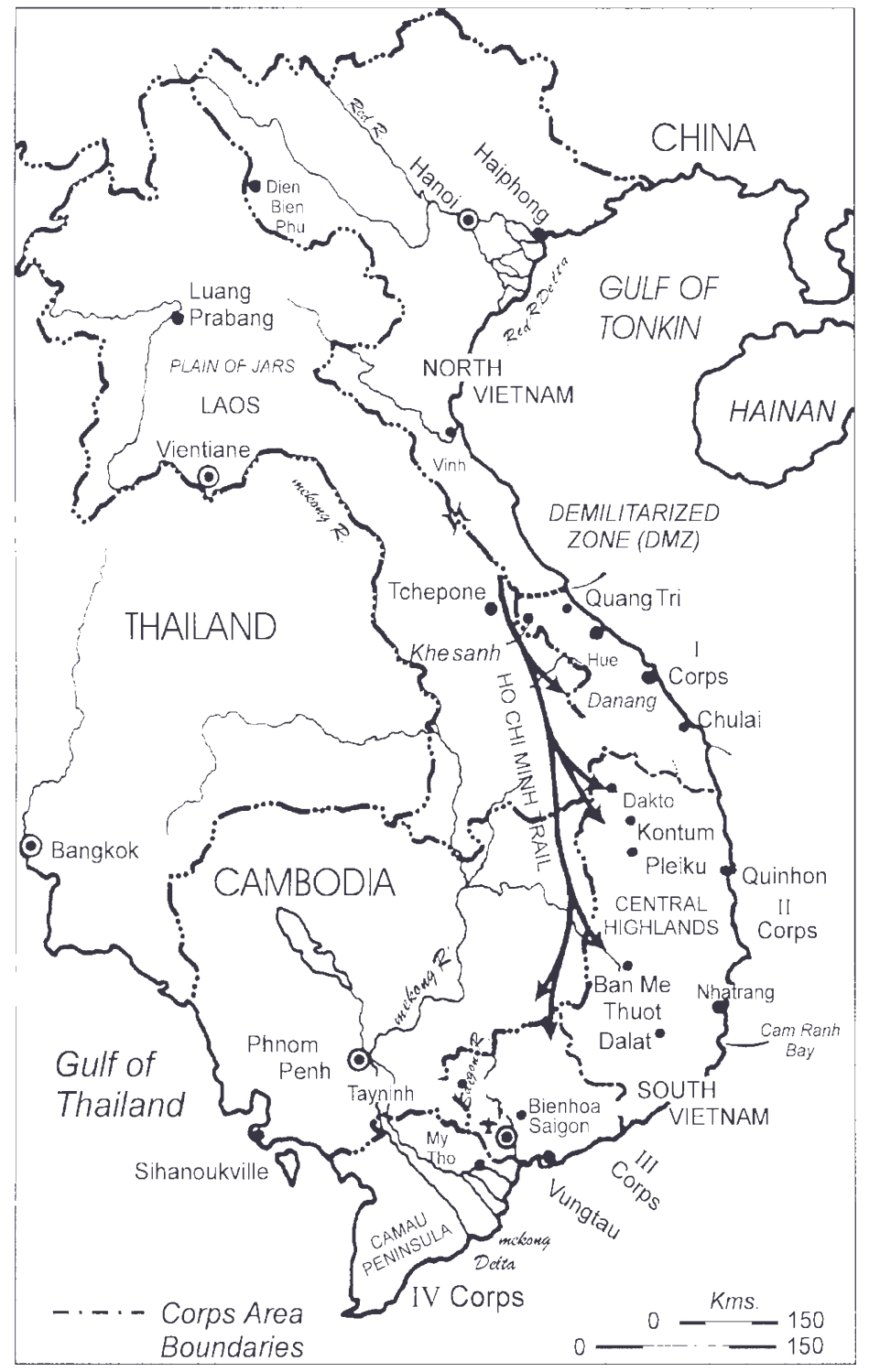

